\title{
OsKar Losy
}

\section{Interpretation of Art. 54 of the Convention Implementing the Schengen Agreement}

\section{Introduction}

Article 54 of the Convention implementing the Schengen Agreement (CISA) ${ }^{1}$ states that:
A person whose trial has been finally disposed of in one Contracting Party may not be prosecuted in another Contracting Party for the same acts provided that, if a penalty has been imposed, it has been enforced, is actually in the process of being enforced or can no longer be enforced under the laws of the sentencing Con- tracting Party.

Although the ne bis in idem principle expressed in this provision has already been the subject of many rulings of the Court of Justice of the European Union ${ }^{2}$ it still raises many doubts among academics and practitioners. In the judgments C-129/14 PPU Spa$s i c^{3}$ and C-398/12 $M_{.}^{4}$, the CJEU settled significant issues for the judicial cooperation in criminal matters pertaining to the interpretation of Art. 54 of the CISA.

In the Spasic case, the CJEU ruled whether enforcement clause provided for in $\mathrm{Ar}$ ticle 54 of the CISA contradicts the Charter of Fundamental Rights of the European Union $^{5}$, which also states the principle of ne bis in idem but does not make its application subject to the condition of execution of the sentence. Second, in the judgment C-398/12

1 Convention implementing the Schengen Agreement of 14 June 1985 between the Governments of the States of the Benelux Economic Union, the Federal Republic of Germany and the French Republic on the gradual abolition of checks and their common borders, 22.09.2000, OJ L 239/19. Hereinafter: CISA.

2 Hereinafter: CJEU.

3 EU:C:2014:586.

4 EU:C:2014:1057.

5 Hereinafter: Charter. 
M., the CJEU ruled on several doubts regarding the interpretation and scope of the term "finally disposed" contained in Art. 54 of the CISA. The reasoning of the CJEU in these two cases differs significantly, which might be surprising given the fact that the issuing dates of these two judgments are separated by only a few days.

The principle of ne bis in idem is well-established regulation in both domestic and international law ${ }^{6}$. The issue of a prohibition of recurring criminal proceedings in the same case and against the same person has been included in the various instruments of international criminal law, including conventions adopted within the Council of Europe, among which the Conventions of $1970^{7}$ and of $1972^{8}$ deserve special attention. In the European Union ${ }^{9}$, the $n e$ bis in idem principle was expressed at first in the framework of European Political Cooperation, before the Treaty of Mastricht. entered into force of the, the Member States - then - the European Community, adopted on 27 May 1987 the Convention on double punishment. Due to the lack of enough ratifications, this Convention has never entered into force. However, it turned out to be important for further development of the judicial cooperation in criminal matters. Its provisions were included in Art. 54-58 of the CISA and are currently applicable to the majority of the EU Member States. In addition, the principle is included in the number of instruments based on the principle of mutual recognition and, as already mentioned at the outset, in the Charter.

\section{Enforcement Clause. Spasic Case C-129/14 PPU}

In accordance with Art. 50 of the Charter: "No one shall be liable to be tried or punished again in criminal proceedings for an offence for which he or she has already been finally acquitted or convicted within the Union in accordance with the law".

In the Charter, therefore, the prohibition of re-judging is not dependent on the condition envisaged in the CISA, i.e. that "the penalty has been imposed, it has been enforced, is actually in the process of being enforced". When trying to explain the differences in the burden of these provisions, it should be noted that the CISA, signed in 1985, was primarily aimed at abolishing checks at common borders, including the abolition of checks in relation to the movement of persons and not fostering judicial cooperation in criminal matters. At that time, the idea of a common area of justice, was not yet expressed in the treaties. The CISA was incorporated into the EU legal order under the Treaty of Amsterdam. Article 54 of the CISA has for the first time successfully in-

6 With regard to the definition of the principle see: A. Sakowicz, Zasada ne bis in idem w prawie karnym w ujęciu paneuropejskim, Białystok 2011.

7 European Convention on the International Validity of Criminal Judgments.

8 European Convention on the Transfer of Proceedings in Criminal Matters.

9 Hereinafter: EU. 
troduced the principle of the prohibition of double punishment, which is applicable in a situation involving criminal proceedings in the two states. Other regulations narrowed the scope of the ne bis in idem principle to domestic matters only. An example of such a regulation is contained in the Protocol to the European Convention on Human Rights of 22 November $1984 .^{10}$

Against the background of the numerous judgments of the CJEU regarding the principle of ne bis in idem ${ }^{11}$, it could be foreseen that it is only a matter of time when the CJEU will decide on the mutual relationship between the provisions of the CISA and the Charter. Ultimately, this was the subject matter of a request for a preliminary ruling from the German court in the case C-129/14 Zoran Spasic. Since the accused was in custody, the case was dealt with in the urgent preliminary ruling procedure ${ }^{12}$. The CJEU issued the verdict quickly, even though the case concerned a very complicated matter. Perhaps the pressure of time influenced somehow the analysis made by the Court and its argumentation, which is not fully convincing in this matter.

Z. Spasic, a citizen of Serbia ${ }^{13}$, was accused of fraud committed to the detriment of a German citizen. The offense was committed in Milan in 2009. Based on a verdict issued in Italy, Z. Spasic was sentenced to one year's imprisonment and a fine of 800 euros. At that time, Z. Spasic was in Austria, where he had served a prison sentence for another offense. For these reasons he paid a fine but was not able to serve the imprisonment sentence for the fraud committed in Italy. Since the crime in Milan was committed against a German citizen, the criminal proceedings were also initiated simultaneously by the German authorities. Under the European arrest warrant issued by the German authorities, Austria transferred Z. Spasic to Germany. As a result, he was in Germany waiting for a trial whose object was a crime for which Z. Spasic had already been convicted in Italy.

In the course of the trial in Germany, the accused referred to the ne bis in idem principle expressed in Art. 50 of the Charter demanding the discontinuance of proceedings. Due to the mentioned differences in the concept of the ne bis in idem principle in various legal instruments, the Higher Regional Court in Nuremberg referred the question for a preliminary ruling to the CJEU, which was intended to clarify the following issue:

10 Protocol No. 7 to the Convention for the Protection of Human Rights and Fundamental Freedoms.

11 Eg.: C-187/01 and C-385/01, Gözütok and Brügge, EU:C:2003:87; C-469/03, Miraglia, EU:C:2005:156; C-436/04, Van Esebroeck, EU:C:2006:165; C-467/04, Gasparini and others, EU:C:2006:610; C-150/05, van Straaten, EU:C:2006:614; C-288/05, Kretzinger, EU:C:2007:441; C-367/05, Kraaijenbrink, EU:C:2007:444; C-297/07, Bourquain, EU:C:2008:708; C-491/07, Turansky, EU:C:2008:768.

12 Hereinafter: PPU.

13 Article 54 of the CISA applies to third-country nationals; Cf. for example, Judgment of the CJEU in joined Cases C-187/01 and C-385/01, Gözütok and Brügge, § 9. 
"Is Article 54 CISA compatible with Article 50 of the Charter, in so far as it subjects the application of the ne bis in idem principle to the condition that, if a penalty has been imposed, it has been enforced, is actually in the process of being enforced or can no longer be enforced under the laws of the sentencing State?"

The court found that the "enforcement clause" is compatible with the Charter. The CJEU came to this conclusion after analysing the provision of Art. 52(1) of the Charter, which sets the rules for admissibility of restrictions of rights and freedoms. This provision provides that all such limitations may be made only if they are necessary and genuinely meet objectives of general interest recognised by the Union or the need to protect the rights and freedoms of others. The CJEU pointed out that enforcement clause is to be seen in that context since it is intended to prevent, in the Area of Freedom, Security and Justice, the impunity of persons definitively convicted and sentenced in the EU Member State. ${ }^{14}$ According to the CJEU, it cannot be contested that the execution condition laid down in Article 54 of the CISA is appropriate. By allowing, in cases of non-execution of the sentence imposed, the authorities of one Member State to prosecute a person definitively convicted and sentenced by another Member State on the basis of the same acts, the risk that the person concerned would enjoy impunity by virtue of his leaving the territory of the State in which he was sentenced is avoided. ${ }^{15}$ The CJEU did not agree with the arguments presented, among others by the European Commission, that the numerous instruments of secondary law based on the principle of mutual recognition at least in a large number of cases can eliminate the risk of impunity. Such instruments - in opinion of the CJEU - are not capable of fully achieving the objective pursued since the existing instruments provided for in the Framework Decisions and the Directives are not perfect enough to guarantee the avoiding of impunity in case where the person concerned would leave the territory of the State in which he was sentenced. In this context - according to the CJEU - the obligation to take direct consultations between Member States on any effective solution aimed at avoiding the negative consequences of parallel proceedings, provided in framework decision on preventing the conflicts of jurisdiction ${ }^{16}$ is also insufficient. With regard to the obligation of mutual support envisaged in Article $4(3)^{17}$ of the Treaty on the European Union, the CJEU stated that one cannot exclude that the Member States can contact each other and initiate consultations in order to verify whether the Member State which imposed

14 Judgment of the CJEU in Case C-129/14 PPU, § 63.

15 Judgment of the CJEU in the Case C-129/14 PPU, § 64.

16 Council Framework Decision 2009/948/JHA of 30 November 2009 on prevention and settlement of conflicts of exercise of jurisdiction in criminal proceedings OJ L 328, 15.12.2009.

17 In accordance with art. 4 (3) of the Treaty on the European Union: "Pursuant to the principle of sincere cooperation, the Union and the Member States shall, in full mutual respect, assist each other in carrying out tasks which flow from the Treaties". 
the first sentence really intends to execute the penalties imposed..$^{18}$ In the opinion of the CJEU, however, it does not change the fact that the enforcement condition provided for in the CISA is necessary and proportionate and therefore justified in the light of the provision of Article 52 (1) of the Charter.

\section{View of Advocate General Jääskinen}

Advocate Genera $1^{19} \mathrm{~N}$. Jääskinen assessed the case differently. In his view ${ }^{20}$, the emergence of a more effective system of cooperation in criminal law matters cannot in itself affect the interpretation of the enforcement clause laid down in Article 54 CISA, however, that development must have some bearing on assessment of its compatibility with $\mathrm{Ar}$ ticle 50 of the Charter. In the opinion of the AG it is questionable whether the enforcement clause in CISA is "still needed in an Area of Freedom, Security and Justice, where cross-border enforcement now takes place through the mutual recognition instruments" ${ }^{\prime 21}$.

In the view, the AG compares the provisions of the Charter to Art. 4 of Protocol 7 to the European Convention on Human Rights ${ }^{22}$, which also establishes the ne bis in idem principle. The AG rightly points out that the wording of the provisions is identical, with the difference that application of Art. 4 of Protocol 7 of ECTHR is limited to domestic issues only. As an exception to the principle ne bis in idem Art. 4 par. 2 of Protocol 7 to the ECHR allows reopening of the case in accordance with the law and penal procedure of the State concerned if there is evidence of new or newly discovered facts, or if there has been a fundamental defect in the previous proceedings, which could affect the outcome of the case. Although Protocol 7 to the ECTHR has not been ratified by all the European Union Member States, the AG believes that there is no doubt that Art. 50 of the Charter should be interpreted in accordance with the provisions of the ECTHR and the relevant case law of the European Court of Human Rights ${ }^{23} .{ }^{24}$ This opinion is supported also by the position of the CJEU reflected in the case C617/10 Åkerberg

18 Judgment of the CJEU in the case C-129/14 PPU, § 63.

19 Hereinafter: ECTHR.

20 View of AG Jääskinen in the case C-129/14 PPU.

21 Ibidem, §52.

22 Hereinafter: AG.

23 Hereinafter: ECHR.

24 AG claims that the fact that some Member States have not ratified Protocol No 7 cannot have any bearing on the interpretation of Article 50 of the Charter, since it does not change the scope of that provision. To conclude otherwise would be tantamount to granting the Member States a unilateral power of interpretation as regards the substance of the European Union's system of fundamental rights. In view of the principle of the autonomy of EU law, in conjunction with the CJEU's task of ensuring its uniform interpretation, such a conclusion must be excluded. 
Fransson. ${ }^{25}$ The analysis of the provisions of both the Charter and the CISA in the light of the ECTHR leads the AG to the following conclusion: 'It is undisputed that the execution condition (enforcement clause) laid down in Article 54 of the CISA makes the application of the ne bis in idem principle subject to additional conditions which are not present in Article 50 of the Charter and which do not correspond to the derogations allowed under Article 4(2) of Protocol 7. ${ }^{26}$ In other words, the enforcement clause is a derogation which does not coincide with the exceptions provided for in Protocol 7 to the ECTHR. In the most important part of the view, the AG points out that the European Union law now offers legal instruments that allow the Member States to enforce criminal sanctions in cases where the convicted person is in another Member State, as well as the exchange of relevant information to avoid impunity. ${ }^{27}$

The AG also notes that a number of secondary legislation in the field of cooperation in criminal matters refers to the ne bis in idem principle, which is not subject to a condition of enforcement of penalty. ${ }^{28}$ For these reasons, in the opinion of the AG, systematically subjecting persons who have already been finally convicted and sentenced in one Member State to a risk of further prosecution in another Member State exceeds the limits of what is appropriate and necessary for the purpose of attaining the objective pursued. ${ }^{29}$ The AG also pointed to the fact that the Member States are obliged not only to interpret, but also to apply the secondary legislation (and thus also the CISA) in accordance with fundamental rights. That obligation may entail a duty not to apply the given instrument (its provisions). ${ }^{30}$ In the final part of the view, the AG concludes that for all the above reasons, the enforcement condition of the CISA in the general application does not meet the proportionality test.

In the AG's opinion, only in three cases the application of the enforcement clause must be considered necessary: the first exception concerns situations that fall within the scope of Article 4(2) of Protocol No 7, as interpreted by the European Court of Human Rights (cases where reopening of the case is allowed). The second exception concerns the perpetrators of crimes which the Member States are required to punish under general rules of international law, such as crimes against humanity, genocide and

25 EU: C:2013:280.

26 View of AG Jääskinen in the Case C-129/14 PPU, § 63.

27 Eg. Framework decision 2008/909/JHA of 27 November 2008 on the application of the principle of mutual recognition to judgments in criminal matters imposing custodial sentences or measures involving deprivation of liberty for the purpose of their enforcement in the European Union or Framework Decision 2008/675/JHA of 24 July 2008 on taking account of convictions in the Member States of the European Union in the course of new criminal proceedings.

28 View of AG Jääskinen in the Case C-129/14 PPU, § 93-100.

29 Ibidem, § 101.

30 In this regard, the AG refers to the judgment of the CJEU of 21.12.2011 in the Joined Cases C-411/10 and 493/10 N.S. and others - EU:C:2011:865. 
war crimes. The third situation pertains to the event of a lasting obstacle to cooperation as regards the execution of judgments; such an obstacle must exist despite the application of the less intrusive instruments available to the Member States.

\section{Assessment of the Ruling of the CJEU in Spasic case}

It is worth pointing out that the analysis of the enforcement clause contained in Art. 54 of the CISA was already carried out by the CJEU in the judgment of 18 July 2007 (Kretzinger case) ${ }^{31}$ In both judgments, i.e. Spasic and Kretzinger, the CJEU has indicated that the purpose of the enforcement clause is to avoid a situation in which a person whose trial has been finally disposed of in the first State can no longer be prosecuted for the same acts and therefore ultimately remains unpunished if the State in which the sentence had first been passed did not enforce the sentence imposed. ${ }^{32}$

It is doubtful if there was a real risk of impunity in the Spasic case. The CJEU analyzes the risk of impunity in the event the perpetrator leaves the territory of the convicting state before the sentence is enforced. In the discussed case, however, it seems that such a risk did not exist.

Z. Spasic was under arrest in Austria. There were no circumstances indicating that the Italian authorities would not take necessary actions in due time to enforce the previously imposed penalty. Secondly, the CJEU categorically accepted that continuing prosecution in the same case in another state would automatically allow avoiding the risk of impunity. However, the mere fact of continuing the prosecution or opening separate proceedings in another Member State does not guarantee that the punishment will be enforced. While it may be argued that parallel proceedings will limit such a risk, there may still be certain circumstances (in the Member State that is taking the case for the second time), which cause that the punishment will never be imposed. The CJEU's argument on the relationship between the enforcement clause and the avoidance of penalty cannot be accepted uncritically, although prima facie it may seem persuasive. One cannot exclude that the second proceedings will end with the discontinuation of the proceedings or with the acquitta ${ }^{33}$. In that case, the conflicting decisions of national courts would create additional difficulties in the judicial cooperation in criminal matters. This would certainly have a negative impact on the level of mutual trust between Member States. The inevitability of punishment is not the only important aspect in the Area of Freedom, Security and Justice. The second proceedings cause to offender - a additional costs and negative mental experiences

31 EU:C:2007:441.

32 Judgment of the CJEU in Case C288/05, § 51.

33 Cf. M. Wasmeier, Ne bis in idem and the enforcement condition. Balancing Freedom, Security and Justice? "New Journal of European Criminal Law" 2014, no. 4. 
associated with the uncertainty of his situation. The CJEU's reasoning focuses entirely on the need to avoid impunity and omits other important aspects such as legal certainty. Also, the remaining arguments of the CJEU regarding the interpretation of the enforcement condition in the context of Art. 52(1) of the Character are not completely accurate. In the opinion of the CJEU, due to the fact that the existing instruments of mutual assistance are not conditional on fulfilling the condition analogous to the enforcement condition, they cannot ensure that the set objective (i.e. avoidance of impunity) is fully achieved. Unfortunately, the CJEU did not consider the more balanced position (supported by the European Commission), which implies the obligation to use all available instruments of cooperation in the EU before initiating the second criminal proceedings against the same person. This position assumes that a possible re-initiation of criminal proceedings would be possible only if all available forms of cooperation have failed. M. Wasmeier has rightly observed that the analysis of the existing cooperation instruments made by the CJEU was not complete ${ }^{34}$. For example, there was no reference to the coordination and mediation provided by Eurojust, which in this case was not only an option but an obligation of the judicial authorities. According to the framework decision on the prevention of conflicts of jurisdiction ${ }^{35}$ the competent authorities of the Member States are required to enter into direct consultations with a view to reaching an agreement on an effective solution that will allow avoiding negative effects of parallel proceedings. This obligation may also be interpreted from Article 57 of the CISA ${ }^{36}$.

The considerations of the CJEU in the Spasic case are not profound. The ruling was issued without the careful examination of all aspects and consequences of application of the enforcement condition.

\section{Final Disposal of the Judgment}

Surprisingly, in other judgments referring to the interpretation of the provision of Art. 54 of the CISA, the CJEU presented a different course of reasoning. In the judgment of joined Cases C-187/01 and C-385/01 - H. Gözütok and K. Brügge ${ }^{37}$, the CJEU

\footnotetext{
34 Ibidem, p. 542.

35 Council Framework Decision 2009/948/JHA of 30 November 2009.

36 In accordance with art. 57 of the CISA: 'Where a Contracting Party charges a person with an offence and the competent authorities of that Contracting Party have reason to believe that the charge relates to the same acts as those in respect of which the person's trial has been finally disposed of in another Contracting Party, those authorities shall, if they deem it necessary, request the relevant information from the competent authorities of the Contracting Party in whose territory judgment has already been delivered'.
}

37 EU:C: 2003:87. 
emphasized the freedom and justice aspects, whereas concerns of impunity seemed to receive not as much attention ${ }^{38}$. The CJEU emphasized that the purpose of Art. 54 of the CISA is to ensure the exercise of the right to free movement in the Schengen Area and that the ne bis in idem principle enshrined in Article 54 of the CISA implies that the Member States have mutual trust in their criminal justice systems and that each of them recognises the criminal law in force in the other Member States even when the outcome would be different if its own national law were applied ${ }^{39}$. Likewise in the case C-150/05 Van Straaten ${ }^{40}$, when answering the question whether the principle ne bis in idem applies to judgments, as a result of which the accused is acquitted due to lack of sufficient evidence, the CJEU stated that in the case of a final acquittal for lack of evidence, the bringing of criminal proceedings in another Contracting State for the same acts would undermine the principles of legal certainty and of the protection of legitimate expectations'. ${ }^{41}$ The interpretation given by the CJEU in these judgments supports the protective nature of the regulation of Art. 54 of the CISA. While interpreting this provision, the CJEU seemed to emphasize that it is intended to counteract the unlimited and unjustified right of punishment (ius puniendi) of the Member States in the area of freedom, security and justice. ${ }^{42}$ The above-mentioned rulings were issued in 2006 and 2013.

Has the CJEU therefore changed its position regarding Art. 54 of the CISA since then and it has lost faith in the means of mutual recognition? Against such argumentation speaks reasoning presented in the case C-398/12 M. ${ }^{43}$ ). This case also concerned the interpretation of Art. 54 of the CISA.

In relation to M., an Italian citizen living in Belgium, criminal proceedings were conducted due to allegations on crimes committed against sexual freedom of a minor. As a result of preparatory proceedings, in the course of which various evidences had been collected and examined, the court of first instance (the court supervising the preparatory proceedings) discontinued the proceedings and did not refer the case to the court ruling on criminal liability due to insufficient evidence. This decision was also upheld by the higher court after the appeal. At the same time, criminal proceedings in a case involving the same acts were initiated in Italy. In this case M. referred to the ne bis in idem principle, indicating that the proceedings for the same acts had already been validly concluded in Belgium. In consequence, there was doubt if a final judgment that terminates criminal proceedings after an investigation, but which permits the proceedings to be reopened in

38 Cf. B. Nita - Światłowska, Prawomocność orzeczenia jako element wyznaczajacy zakres zasady ne bis in idem w art. 54 Konwencji z Schengen, „Europejski Przegląd Sądowy”2014, no.5, p.30.

39 Judgment of the CJEU in Case C-187/01 and C-385/01, §33.

40 EU:C: 2006:614.

41 Judgment of the CJEU in Case C-150/05, § 59.

42 M. Wasmeier, The principle of ne bis in idem, "Revue Internationale de Droit Penal" 2006, no. 1-2, pp. 121-130.

43 EU:C: 2014:1057. 
the light of new evidence, preclude the initiation or conduct of proceedings in respect of the same facts and the same person in another Member States. The CJEU answered the question in the affirmative. Its arguments resemble those which were previously presented in the cases of Gözütok/Brügge and Van Straaten presented above.

In the first place, the CJEU recalled that in order to determine if a judicial decision constitutes a 'final' judgment ${ }^{44}$ in the meaning of Art 54 of the CISA, it must be ensured that that decision was issued following the assessment of the merits of the case. ${ }^{45}$ The aptness of that interpretation of Article 54 of the CISA is borne out by the fact that it is the only interpretation to give precedence to the object and purpose of the provision rather than to procedural or purely formal matters. In the M. case the decision on discontinuance of proceedings was made at the end of an investigation during which various items of evidence were collected and examined. Therefore, in the opinion of the court, the decision met the condition of assessment of the merits of the case.

In a further part of the judgment, the CJEU stated that the possibility of reopening the criminal investigation if new facts and/or evidence become available, cannot affect the final nature of the order of the national court. ${ }^{46}$ In this regard, the CJEU indicated that Art. 54 of the CISA should be interpreted in the light of Art. 50 of the Charter and as a consequence ${ }^{47}$ also in the light of Art. 4(2) Protocol No. 7 to the ECHR. These provisions provide that the principle ne bis in idem does not preclude the possibility of resuming the proceedings if there is evidence of new or newly discovered facts. It his respect, it was held in the judgment of the ECHR in Sergey Zolutukhin v. Russia, ${ }^{48}$ that Article 4 of Protocol No 7 to the ECHR 'becomes relevant on commencement of a new prosecution, where a prior acquittal or conviction has already acquired the force of res judicata.' On the other hand, extraordinary remedies are not taken into account for the purposes of determining whether the proceedings have reached a final conclusion.

Moreover, the CJEU stressed that in view of the need to verify that the evidence relied on to justify the reopening of the proceedings is indeed new, any new proceedings, based on such a possibility of reopening, against the same person for the same acts can be brought only in the Contracting State in which that order was made'. ${ }^{49}$ In con-

44 With regard to the condition of 'final disposal' of the case see also: B. Nita - Swiatłowska, Prawomocnośc orzeczenia..., op.cit. ;B. Nita, Artykut 54 konwencji wykonawczej z Schengen w wyrokach Europejskiego Trybunału Sprawiedliwości z 28 września 2006 r.: C-467/04, postępowanie karne przeciwko Giuseppe Francesco Gasparini i innym oraz C-150/05, Jean Leon Van Straaten przeciwko Niderlandom i Republice Wtoskiej, „Europejski Przegląd Sądowy” 2007, no. 9, pp. 44-52; A. Soltysińska, Zasada ne bis in idem z art. 54 konwencji wykonawczej z Schengen, „Europejski Przegląd Sądowy” 2007, no. 12.

45 Judgment of the CJEU in the Case C469/03 - Filomeno Mario Miraglia; EU:C:2005:156.

46 Judgment of the CJEU in Case C469/03, § 40.

$47 \mathrm{Cf}$. Judgment of the CJEU in the Case C617/10.

48 Sergey Zolutukhin v. Russia, no. 14939/03, § 83, ECHR 2009.

49 Judgment of the CJEU in the Case C398/12, § 40. 
clusion, the CJEU held that order finding that there is no ground to refer a case to a trial court which precludes, the bringing of new criminal proceedings in respect of the same acts against the person to whom that finding applies, unless new facts and/or evidence against that person come to light, must be considered to be a final judgment, for the purposes of the Article 54 of the CISA.

In this case, the CJEU in its reasoning did not refer to arguments related to broadly understood security or impunity, although the subject matter of the case at first glance seemed at least as sensitive as in the case of Spasic. It also stressed the impact of the Charter on the interpretation of rules set in the CISA.

\section{Conclusions}

Regarding the Spasic case, it is difficult to see the need for additional criminal proceedings in the absence of a real threat that the penalty will not be enforced. It is regrettable that the CJEU has not thoroughly analysed all the existing advanced possibilities of judicial cooperation in criminal matters in the EU, which allow minimizing the risk of impunity to the extreme and rare cases. The consequences for the accused related to parallel proceedings are severe. In this context, the position of the AG, according to which the initiation of another criminal case in another Member State is possible only in three exceptional cases, is more convincing and balanced. Permission granted by the CJEU to unlimited application of the enforcement clause with omission of the secondary law instruments and wording of Art. 50 of the Charter is an extreme position. It may also be surprising that in the Spasic case, the CJEU as the only criterion accepted the necessity of preventing impunity without considering other important aspects including legal certainty.

The reasoning in the Spasic case is in contradiction with the judgment in the M. case, issued just a few days later. In the latter, the CJEU underlined that a Member State must comply with a final decision that has already been passed in another Member State, even when the outcome of the case would be different if its own national law were applied.

The ruling of the CJEU in the M. case seems to share the arguments of the previous judgments in the Gözütok/Brügge cases, where the primacy was given to the freedom of movement and legal certainty. Differences in the adopted legal hierarchy and the way in which decisions in the Spasic and M. cases are justified might be surprising given that the judgments were issued in the same period. Such a contradict ruling is detrimental for the creation of the European Union's Area of Freedom, Security and Justice. 
194 | Adam Mickiewicz University Law Review

\section{Literature}

Barwina Z., Zasada wzajemnego uznawania w sprawach karnych, Warszawa 2012.

Klimek M., Mutual Recognition of Judicial Decisions in European Criminal Law, Bratislava 2017.

Nita-Światłowska B., Odmienność ujęcia zasady ne bis in idem w Karcie Praw Podstawowych Unii Europejskiej oraz w konwencji wykonawczej z Schengen, „Przegląd Sądowy” 2015, no. 3 .

Nita-Światłowska B., Artykut 54 konwencji wykonawczej z Schengen w wyrokach Europejskiego Trybunału Sprawiedliwości z 28 września 2006 r.: C-467/04, postępowanie karne przeciwko Giuseppe Francesco Gasparini i innym oraz C-150/05, Jean Leon Van Straaten przeciwko Niderlandom i Republice Wtoskiej, „Europejski Przegląd Sądowy” 2007, no. 9.

Sakowicz A., Zasada ne bis in idem w prawie karnym w ujęciu paneuropejskim, Białystok 2011.

Wasmeier M., Ne bis in idem and the enforcement condition. Balancing Freedom, Security and Justice?, "New Journal of European Criminal Law" 2014, no. 4.

Wasmeier M,. The principle of ne bis id idem, "Revue Internationale de Droit Penal" 2006, 1-2.

Convention implementing the Schengen Agreement of 14 June 1985 between the Governments of the States of the Benelux Economic Union, the Federal Republic of Germany and the French Republic on the gradual abolition of checks and their common borders, 22.09.2000, OJ L 239/19.

Charter of Fundamental Rights of the European Union of 30 March 2010, OJ C 83/389.

\section{SUMMARY}

\section{Interpretation of Art. 54 of the Convention Implementing the Schengen Agreement}

The paper discusses the problem of the ne bis in idem principle stipulated in the Convention Implementing the Schengen Agreement (CISA) and the Charter of Fundamental Rights of the European Union. Article 54 of the CISA makes the application of the principle ne bis in idem subject to the condition of execution of the penalty. An analogous condition is not provided for in the Charter. These differences caused doubts regarding the application of the ne bis in idem principle and were subject of the question for preliminary ruling in the Spasic case (C-129/14 PPU). The paper contains a critical review of the reasoning of the Court of Justice of the European Union in this judgment. In addition, the article also contains an analysis of the CJEU's decision in Case C-398/12 M. in which the CJEU has analysed the meaning of "final disposal" of the judgment in the 
context of the ne bis in idem principle. Based on the above judgments, the article presents arguments indicating that the reasoning of the CJEU on the conditions for the application of the ne bis in idem principle in judicial cooperation in criminal matters in the EU is not consistent.

Keywords: European criminal law; Area of Freedom; Security and Justice; ne bis in idem principle; mutual trust; mutual recognition.

Oskar Losy, Adam Mickiewicz University Poznań, Faculty of Law and Administration, Al. Niepodległości 53, 61-714 Poznań, Republic of Poland, e-mail: oskar.losy@amu.edu.pl. 
